\title{
Acute and Subchronic Toxicity Assessment of Proteins from Plumeria pudica Latex
}

\section{in Mice}

\author{
Avaliação de toxicidade aguda e subcrônica de proteínas do látex de Plumeria pudica em \\ camundongos
}

Evaluación de la toxicidad aguda y subcrónica de las proteínas de látex de Plumeria pudica en ratones

Naylla Veras de Moraes Oliveira ORCID: https://orcid.org/0000-0003-0961-5098 Universidade Federal do Delta do Parnaíba, Brazil E-mail: nayllamoraes@ hotmail.com

Lucas Arruda Moita

ORCID: https://orcid.org/0000-0002-9713-7091 Universidade Federal do Delta do Parnaíba, Brazil E-mail: lucasarrudamoita@gmail.com

Lucas Eduardo Silva Oliveira

ORCID: https://orcid.org/0000-0002-1657-3984

Universidade Federal do Delta do Parnaíba, Brazil E-mail: 1cseduardo3@hotmail.com

Felipe Cardoso de Brito

ORCID: https://orcid.org/0000-0002-9040-1726 Instituto Federal do Piauí, Brazil E-mail: felipe.cardoso@ifpi.edu.br

Felipe Rodolfo Pereira da Silva

ORCID: https://orcid.org/0000-0001-9224-5571

Universidade Federal do Amazonas, Brazil E-mail: feliperodolfo.15@hotmail.com

Luiz Felipe de Carvalho França ORCID: https://orcid.org/0000-0001-5361-8603

Universidade Federal do Delta do Parnaíba, Brazi E-mail: phelpscf@hotmail.com

Francisca Beatriz Melo Sousa

ORCID: https://orcid.org/0000-0001-5265-2009

Universidade Federal do Delta do Parnaíba, Brazil

E-mail: frcabeatriz.melo@hotmail.com

Anna Carolina Toledo Cunha Pereira

ORCID: https://orcid.org/0000-0001-7009-9876

Universidade Federal do Delta do Parnaíba, Brazil E-mail: actcp@ufpi.edu.br

Gustavo Portela Ferreira

ORCID: https://orcid.org/0000-0002-2329-9389

Universidade Federal do Delta do Parnaíba, Brazil E-mail: gtvpf@ufpi.edu.br

Jand-Venes Rolim Medeiros

ORCID: https://orcid.org/0000-0002-7234-3382

Universidade Federal do Delta do Parnaíba, Brazi

E-mail: jandvenes@ufpi.edu.br

Cleverson Diniz Teixeira de Freitas

ORCID: https://orcid.org/0000-0002-2203-1575 Universidade Federal do Ceará, Brazil E-mail: cleversondiniz@ hotmail.com

Daniel Fernando Pereira Vasconcelos

ORCID: https://orcid.org/0000-0002-3331-452X

Universidade Federal do Delta do Parnaíba, Brazil

E-mail: vasconcelos@ufpi.edu.br 


\begin{abstract}
Latex proteins extracted from Plumeria pudica (LPPp) have anti-inflammatory activity in different experimental models. Considering this relevant result, we evaluated the toxicological aspects of the treatment of mice with LPPp. Acute and subchronic toxicities were determined by daily intraperitoneal administration of $40 \mathrm{mg} / \mathrm{kg}$ of LPPp for 10 or 20 days, respectively, and were followed by behavioral, hematological, biochemical and histopathological evaluation. Results showed no significant changes in body weight and organs of animals treated with LPPp. Total and differential blood leukocyte counts of LPPp groups did not differ from controls. There was no significant difference in aspartate aminotransferase, alanine aminotransferase, creatinine and urea measurements for the group treated for 20 days. The level of glutathione in the kidney was significantly higher in animals treated with LPPp in the acute toxicity test, but no differences were observed for the subchronic evaluation. The concentration of malondialdehyde and myeloperoxidase activity in the organs did not differ from controls. Histopathological examination of kidney, spleen and liver tissue of animals treated with LPPp revealed normal structures or reversible alterations. Intraperitoneal $\mathrm{LD}_{50}$ of LPPp was higher than $2,000 \mathrm{mg} / \mathrm{kg}$. The data obtained reveal that LPPp is nontoxic at $40 \mathrm{mg} / \mathrm{kg}$.
\end{abstract}

Keywords: Laticiferous proteins; Toxicological evaluation; Nontoxic; $\mathrm{LD}_{50}$.

\title{
Resumo
}

Proteínas extraídas do látex de Plumeria pudica (LPPp) apresentam atividade anti-inflamatória em diferentes modelos experimentais. Diante desse relevante resultado, avaliamos os aspectos toxicológicos do tratamento de camundongos com LPPp. A toxicidade aguda e subcrônica foram determinadas pela administração intraperitoneal diária de 40 $\mathrm{mg} / \mathrm{kg}$ de LPPp por 10 ou 20 dias, respectivamente, e foram seguidas por avaliação comportamental, hematológica, bioquímica e histopatológica. Os resultados não mostraram alterações significativas no peso corporal e órgãos dos animais tratados com LPPp. A contagem total e diferencial de leucócitos no sangue dos grupos LPPp não diferiu dos controles. Não houve diferença significativa nas medidas de aspartato aminotransferase, alanina aminotransferase, creatinina e uréia para o grupo tratado por 20 dias. O nível de glutationa nos rins foram significativamente maior nos animais tratados com LPPp no teste de toxicidade aguda, mas nenhuma diferença foi observada para a avaliação subcrônica. A concentração de malondialdeído e a atividade da mieloperoxidase nos órgãos não diferiram dos controles. O exame histopatológico do tecido renal, do baço e do fígado de animais tratados com LPPp revelou estruturas normais ou alterações reversíveis. A $\mathrm{DL}_{50}$ de LPPp administrada por via intraperitoneal foi superior a 2.000 $\mathrm{mg} / \mathrm{kg}$. Os dados obtidos revelam que LPPp não é tóxico na dose de $40 \mathrm{mg} / \mathrm{kg}$.

Palavras-chave: Proteínas laticíferas; Avaliação toxicológica; Não tóxico; DL 50.

\section{Resumen}

Las proteínas extraídas del látex de Plumeria pudica (LPPp) tienen actividad antiinflamatoria en diferentes modelos experimentales. Ante este relevante resultado, evaluamos los aspectos toxicológicos del tratamiento de ratones con LPPp. La toxicidad aguda y subcrónica se determinó mediante la administración intraperitoneal diaria de $40 \mathrm{mg} / \mathrm{kg} \mathrm{de}$ LPPp durante 10 o 20 días, respectivamente, y fueron seguidas por evaluación conductual, hematológica, bioquímica e histopatológica. Los resultados no mostraron cambios significativos en el peso corporal y los órganos de los animales tratados con LPPp. El recuento de leucocitos total y diferencial en la sangre de los grupos LPPp no difirió de los controles. No hubo diferencias significativas en las mediciones de aspartato aminotransferasa, alanina aminotransferasa, creatinina y urea para el grupo tratado durante 20 días. El nivel de glutatión en los riñones fue significativamente mayor en los animales tratados con LPPp en la prueba de toxicidad aguda, pero no se observaron diferencias para la evaluación subcrónica. La concentración de malondialdehído y la actividad de la mieloperoxidasa en los órganos no difirieron de los controles. El examen histopatológico del tejido renal, el bazo y el hígado de los animales tratados con LPPp reveló estructuras normales o cambios reversibles. $L a L_{50}$ de LPPp administrada por vía intraperitoneal fue superior a $2000 \mathrm{mg} / \mathrm{kg}$. Los datos obtenidos revelan que LPPp no es tóxico a dosis de $40 \mathrm{mg} / \mathrm{kg}$.

Palabras clave: Proteínas lácteas; Evaluación toxicológica; No tóxico; DL 50.

\section{Introduction}

Although many plants are commonly used in traditional medicine to ameliorate the symptoms of several diseases, they may contain toxic molecules that cause serious harm to animals and/or humans (Veiga-Júnior, Pinto, Maciel, 2005; Subramanian, Sankaramourthy, Gunasekaran,2018; Memariani et al,2020). The toxicity of medicinal plants is considered a public health problem since this can affect a large number of people (Oliveira \& Almeida, 2016). Thus, the development of 
studies of plant species of clinical interest is important to ensure safe use and reduce the risk of toxicity (Mengue, Ments, Schenkel, 2001; Silveira, Bandeira, Arrais, 2008; Christapher et al, 2017). According to the World Health Organization (WHO), $80 \%$ of the world's population use alternative therapies to treat health problems, and medicinal plants are the main remedies used (Who, 2013). Although medicinal plans are used by a large number of people, frequent use does not prove their effectiveness or the absence of toxicity. Therefore, it is fundamental to have knowledge about the doses that produce effective and toxic effects, commonly obtained by standardized pharmacodynamic and toxicological studies, respectively (Agra, França, Barbosa-Filho, 2007).

Plants producing latex are described as potential sources of molecules with pharmacological properties (Agrawal \& Konno, 2009). In this context, various species of the genus Plumeria are known for their medicinal properties (Shinde, Patil, Bairagi; 2014). Several reports have shown the pharmacological properties of latex, such as anti-inflammatory, antinociceptive, antioxidant, antibacterial, antifungal and gastroprotective (Gupta, et al, 2006; Baghel et al, 2010; Alencar et al, 2015; Fernandes et al,2015). However, despite these reports and the description of popular use of laticiferous plants against different diseases, adverse effects have also been observed (Ramos et al, 2007).

Plumeria pudica (Jacq., 1760) is a latex-producing plant belonging to the Apocynaceae family. The plant, commonly called "bridal bouquet", is found abundantly in northeastern Brazil, where its raw latex is used in particular by poor people to treat skin diseases and tooth pain. In tradition system of India, the plant is widely used for the treatment of diarrhea, bronchitis, cure of itch and other disorders (Devprakash et al, 2012; Choudhary, Kumar, Singh,2014; Dwivedi, Shriwas, Dubey,2017). Recently, it was demonstrated that a well-defined water-soluble protein fraction obtained from the latex of P. pudica (LPPp) has potent anti-inflammatory, antidiarrheal effects and has protective effect during ulcerative colitis and reduce ligature-induced periodontitis in rats (Fernandes et al,2015; Santana et al,2018, Oliveira et al,2019. Oliveira et al,2021). In these studies, the authors showed that intraperitoneal administration of LPPp at $40 \mathrm{mg} / \mathrm{kg}$ produces these effects by modulating important inflammatory mediators such as prostaglandin E2, TNF- $\alpha$ and IL1- $\beta$, as well as by preventing tissue oxidative stress, evaluated by measuring tissue activity of superoxide dismutase and levels of malondialdehyde and reduced glutathione. Although interesting results have been obtained from LPPp studies, its possible toxic effects still need to be investigated. Thus, the goal of the present study was to enhance the toxicological knowledge of LPPp.

\section{Methodology}

This is quantitative and experimental study carried out under controlled conditions (Sampieri et al., 2013).

\subsection{Plant material and latex processing}

Fresh latex was collected in tubes $(1: 1, \mathrm{v} / \mathrm{v}$ in distilled water) from the aerial parts of wild $P$. pudica growing in Parnaíba, Brazil ( ${ }^{\circ} 54^{\prime} 28.4^{\prime \prime}$; $\left.41^{\circ} 46^{\prime} 37.1^{\prime \prime W}\right)$. The plant voucher (sample specimen no. 2,432) used for identification of the botanical material collected is deposited at the Delta do Parnaíba Herbarium of Federal University of Piauí, Brazil. The latex collected was processed as previously described (Fernandes et al, 2015). During collection, the latex was placed in distilled water at a dilution ratio of 1:1 (v/v) and the mixture was gently stirred. Afterward, the samples were taken to the laboratory and centrifuged at $3.600 \times \mathrm{g}$ for $15 \mathrm{~min}$ at $25{ }^{\circ} \mathrm{C}$. The supernatant was thoroughly dialyzed against distilled water using membranes of $8 \mathrm{kD}$ molecular weight cut-off. After dialysis, the material was centrifuged again as described above. The supernatant was lyophilized (designated latex proteins from Plumeria pudica - LPPp) for use in the experiments. 


\subsection{Experimental design}

\subsubsection{Animals}

Adult (8-12 weeks) female Swiss mice (Mus musculus) were obtained from the Central Animal House of Federal University of Piauí. Animals were kept in cages with free access to food and water and were maintained under a 12-h lightdark cycle (lights on at 6 a.m.) at $25{ }^{\circ} \mathrm{C}$. All experimental procedures with animals were performed in accordance with the guidelines of the National Institutes of Health guide for the care and use of Laboratory animals (NIH Publications No. 8023, revised 1978) and approved by Institutional Animal Ethics Committee from Federal University of Piauí (protocol no. 037/15).

\subsubsection{Acute toxicity test}

For the determination of acute toxicity, the method recommended by the Organization for Economic Cooperation and Development (OEDC) Guideline 423 (2002) was used, with modifications. Two experimental groups were established ( $\mathrm{n}=6$ females): a control group (treated with saline) and a test group (treated with LPPp). LPPp was administered at a dose of 40 $\mathrm{mg} / \mathrm{kg}$ body weight, by intraperitoneal route for 10 consecutive days. Body weights of mice in each group were recorded before the start of treatment and every other day for the entire treatment duration. Changes in body weight of mice were calculated at the end of the 10-day period for the treatment and control groups. Since pharmacological activity documented for LPPp was reached when the animals were pretreated with an intraperitoneal route with doses of $40 \mathrm{mg} / \mathrm{kg}$ (Fernandes et al,2015; Santana et al,2018; Oliveira et al,2019; Oliveira et al,2021) our investigation was performed with this dose and route of administration.

\subsubsection{Subchronic toxicity test}

For the study of subchronic toxicity, the method of the OECD guideline 407 (2008) was used with modifications. Two experimental groups were established ( $\mathrm{n}=6$ females): a control group (treated with saline) and a test group (treated with LPPp). LPPp was administered at a dose of $40 \mathrm{mg} / \mathrm{kg}$ body weight by intraperitoneal route for 20 consecutive days. Body weights of mice in each group were recorded before the start of treatment and every other day for the entire treatment duration. Changes in body weight of mice were calculated at the end of the 20-day period for the treatment and control groups.

\subsection{Cellular and biochemical analyses of blood}

Following the completion of treatment on the 11th and 21st day, the mice in each group were anaesthetized by i.p. administration of ketamine $(60 \mathrm{mg} / \mathrm{kg}) \pm$ xylazine $(8 \mathrm{mg} / \mathrm{kg})$. Blood samples were collected from each mouse by cardiac puncture. Sample bottles with and without ethylenediaminetetraacetic acid (EDTA) were respectively used for collection of blood samples for hematological analyses (total and differential leucocyte count) and biochemical analyses. Cell counting was performed with an optical microscope. The non-heparinized blood was allowed to coagulate and centrifuged at 5,000 x $g$ for 10 min after collection. The serum was analyzed for biochemical parameters: aspartate aminotransferase (AST), alanine aminotransferase (ALT), creatinine and urea, according to the manufacturer's instructions for the kits used (Labtest).

\subsection{Harvesting of organs and histopathological examination}

Liver, kidney and spleen were removed, weighed and immediately sent for histopathological processing. For histopathological examination, sections of liver, kidney, spleen, extracted from experimental mice were fixed in 10\% buffered formalin. Then the samples were dehydrated in graded alcohol (Dinâmica), immersed in xylene (Cromoline) and embedded in paraffin (Dinâmica). Sections with $5 \mathrm{~mm}$ thickness were cut and stained with hematoxylin-eosin (H\&E) (Dinâmica). 
Histopathological analysis consisted of observation of tissue integrity by searching for injuries, such as congestion of vessels and capillaries, degeneration, necrosis, apoptosis and infiltration of leukocytes, which could indicate signs of toxicity.

\subsection{Cellular stress assessment}

Representative samples of vital organs (liver, kidney and spleen) were used for measurement of malondialdehyde (MDA) by the method previously described (Uchiyama \& Mihara,1978) The reduced glutathione (GSH) level was measured according to (Sedlak \& Lindsay,1968). Myeloperoxidase (MPO) activity was determined as previously described by (Bradley et al, 1982).

\subsection{Lethal dose $\left(\mathrm{LD}_{50}\right)$}

The $\mathrm{LD}_{50}$ was assessed according to the experimental protocol of the OECD guideline 423 (2002). After administration of a single dose of $300 \mathrm{mg} / \mathrm{kg}$ or $2,000 \mathrm{mg} / \mathrm{kg}$ of LPPp, the animals were observed closely for the first $8 \mathrm{~h}$ and thereafter once a day for 14 days. In addition, the animals were also observed for general health and clinical signs of toxicity, following the criteria previously used by (Brito, 1994).

\subsection{Statistical analysis}

Results are shown as mean \pm standard error of the mean (SEM). Statistical analysis was carried out using one-way analysis of variance (ANOVA) with the Student-Newman-Keuls test and Tukey multiple comparison test using GraphPad Prism 5 (GraphPad Software, Inc., La Jolla, CA, USA). Significance was considered as $P<0.05$.

\section{Results}

\subsection{Effects of LPPp on body weights of mice}

The mice were monitored for body weight throughout the acute (10 days) and subchronic ( 20 days) treatment assays. The weight of the animals was recorded prior to administration of $40 \mathrm{mg} / \mathrm{kg}$ of LPPp and every other day of the experiment. The weights of the animals treated with LPPp are presented in Figure 1. LPPp did not interfere in the ponderal development of the animals. No significant differences were noted body weight between groups treated with LPPp and saline control group for both acute and subchronic toxicity $(P>0.05)$.

Figure 1. Body weight of mice treated intraperitoneally with latex proteins from Plumeria pudica (LPPp) on acute (left) and subchronic (right) toxicity. Data are presented as mean \pm SEM of six animals. No statistical difference was observed between groups. ANOVA followed by Student Newman-Keuls test, $P>0.05$.
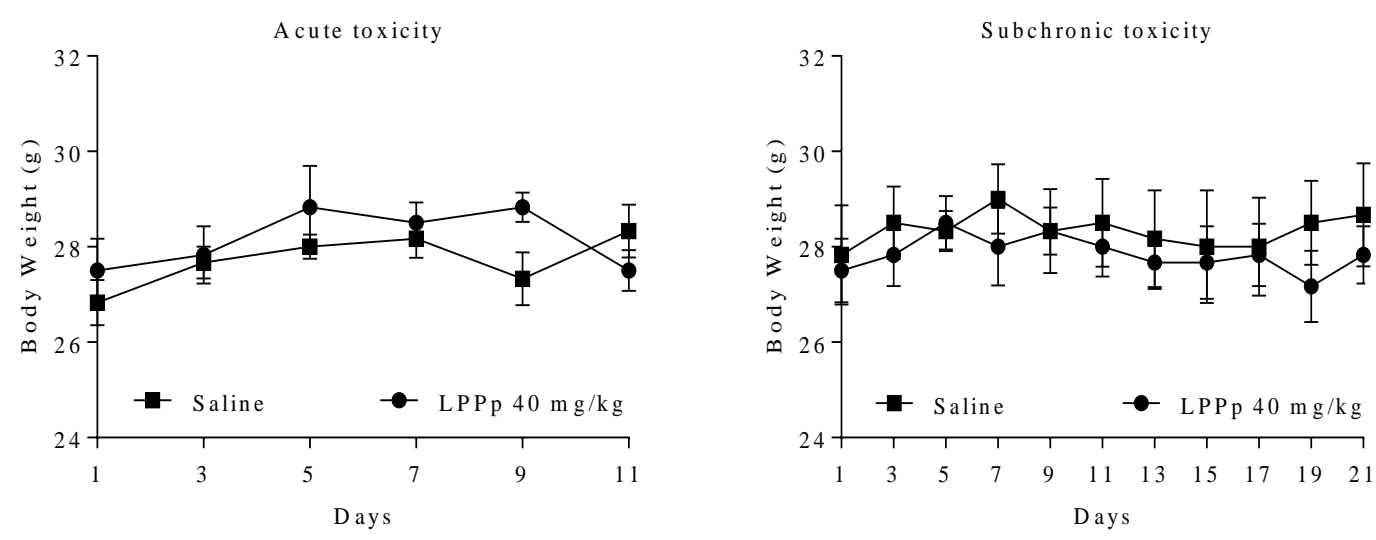

Source: Authors. 


\subsection{Effects of LPPp on Total and differential leukocyte count from the peripheral blood}

Immediately before euthanization, blood samples were collected from the animals for evaluation of hematological parameters. The results of total and differential blood leukocyte count are summarized in Table 1. The animals tested for the acute and subchronic toxicity with intraperitoneal injection of LPPp had results similar to the control animals (saline), and no significant differences were noted between groups submitted to 10 and 20 days of treatment.

\subsection{Effects of LPPp on Blood biochemical parameters}

For the analysis of LPPp toxicity, the biochemical parameters of hepatotoxicity markers were measured in the blood (Table 2). The results revealed a significant increase of AST in the group treated with LPPp $40 \mathrm{mg} / \mathrm{kg}$ for 10 days (acute toxicity) compared to the saline control. However, no significant differences were observed in the AST level between the LPPp group treated for 20 days (subchronic toxicity) and the saline group. For ALT, there was no significant difference between saline and LPPp groups for both acute and subchronic toxicity. Concerning the markers of renal function, there were no significant differences in urea and creatinine content between saline and LPPp groups for animals treated during 10 or 20 days (Table 2).

\subsection{Effects of LPPp on organ weights}

After sacrifice, the liver, spleen and kidneys of mice treated with LPPp $40 \mathrm{mg} / \mathrm{kg}$ or saline in acute and subchronic toxicity evaluation assays were collected and the mean weights of organs were determined (Table 3). The weights of the organs of experimental groups treated with LPPp for both acute toxicity evaluation and subchronic toxicity assessment did not differ significantly from the controls receiving only the saline as vehicle during the same evaluation time.

\subsection{Effects of LPPp on myeloperoxidase activity}

Tissue samples of organs were collected to investigate cellular inflammatory parameters by measurement of myeloperoxidase (MPO) enzyme activity. The MPO activity in the liver, kidneys and spleen of groups treated with LPPp was not significantly different compared to their respective control groups during the 10 days of acute or 20 days of subchronic evaluation (Figure 2).

Figure 2. Effects of latex proteins from Plumeria pudica (LPPp) on myeloperoxidase activity (MPO) in liver, kidney and spleen of animals submitted to acute and subchronic toxicity tests. Data are presented as mean \pm SEM of six animals. No statistical difference was observed between groups. ANOVA followed by Student Newman-Keuls test, $P>0.05$.
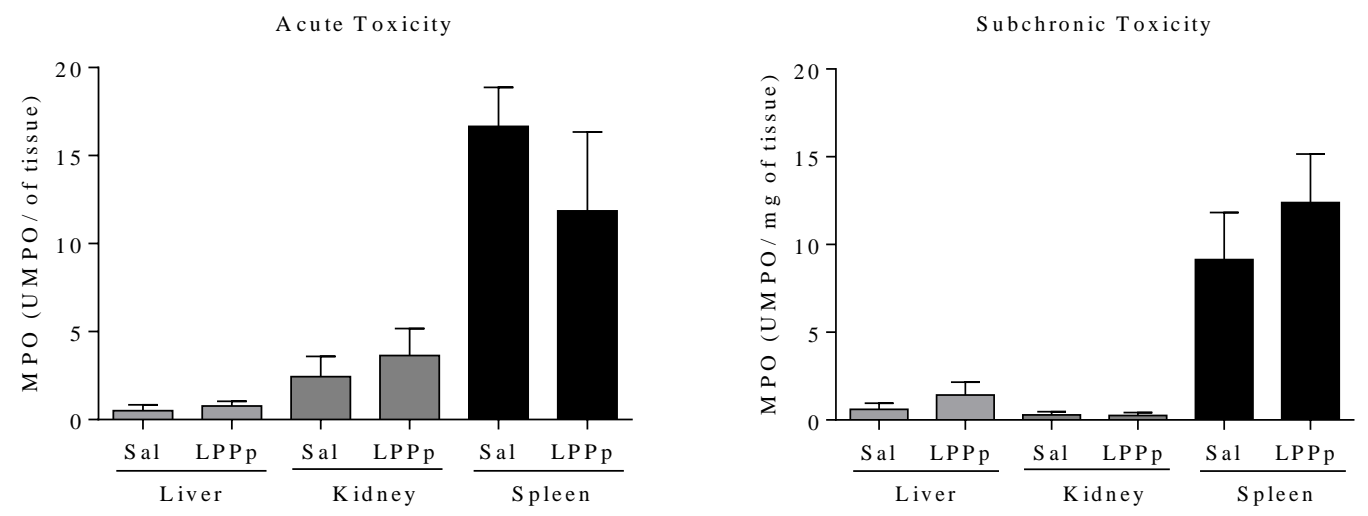

Source: Authors. 
Table 1. Total and differential leukocyte count from the peripheral blood of mice treated with latex proteins from Plumeria pudica (LPPp) on acute and subchronic toxicity.

\begin{tabular}{|c|c|c|c|c|c|c|c|c|}
\hline & \multirow{2}{*}{ Treatment } & \multirow{2}{*}{$\begin{array}{c}\text { Dose } \\
\text { (mg/kg/day) }\end{array}$} & \multirow{2}{*}{$\begin{array}{c}\text { Total leukocytes } \\
\left(10^{3} \text { cells } / \mu \mathrm{l}\right)\end{array}$} & \multicolumn{5}{|c|}{ Count differential of leukocytes $\left(10^{3}\right.$ cells $\left./ \mu \mathrm{l}\right)$} \\
\hline & & & & Basophil & Eosinophil & Neutrophil & Lymphocyte & Monocyte \\
\hline Acute & Saline & - & $5.680 \pm 0.482$ & $0.009 \pm 0.009$ & $0.125 \pm 0.053$ & $0.752 \pm 0.122$ & $4.601 \pm 0.525$ & $0.192 \pm 0.058$ \\
\hline Toxicity & LPPp & 40 & $5.233 \pm 0.435$ & $0.044 \pm 0.016$ & $0.098 \pm 0.043$ & $0.779 \pm 0.172$ & $4.169 \pm 0.530$ & $0.143 \pm 0.032$ \\
\hline Subchronic & Saline & - & $5.947 \pm 0.398$ & $0.030 \pm 0.020$ & $0.019 \pm 0.013$ & $1.217 \pm 0.116$ & $4.367 \pm 0.393$ & $0.156 \pm 0.036$ \\
\hline Toxicity & LPPp & 40 & $5.467 \pm 0.391$ & $0.000 \pm 0.000$ & $0.019 \pm 0.012$ & $0.836 \pm 0.075$ & $4.400 \pm 0.339$ & $0.211 \pm 0.043$ \\
\hline
\end{tabular}

Data are presented as mean \pm S.E.M. of six animals. No statistical significance was observed among groups. ANOVA followed by Student Newman-Keuls, $p>0.05$. Source: Authors.

Table 2. Blood biochemical parameters of mice treated with latex proteins from Plumeria pudica (LPPp) on acute and subchronic toxicity.

\begin{tabular}{|c|c|c|c|c|c|c|}
\hline \multirow{2}{*}{ Parameters } & \multicolumn{3}{|c|}{ Acute Toxicity } & \multicolumn{3}{|c|}{ Subchronic Toxicity } \\
\hline & Saline & LPPp & $P$-value & Saline & LPPp & P-value \\
\hline AST (IU/L) & $111.90 \pm 4.92$ & $245.10 \pm 25.88$ & $0.0047 *$ & $166.10 \pm 30.51$ & $125.30 \pm 27.07$ & 0.6181 \\
\hline ALT (IU/L) & $64.31 \pm 2.95$ & $49.76 \pm 5.23$ & 0.4594 & $57.40 \pm 5.96$ & $45.61 \pm 8.78$ & 0.5648 \\
\hline Urea $(\mathrm{mEg} / \mathrm{L})$ & $56.62 \pm 3.34$ & $54.09 \pm 1.14$ & 0.9926 & $72.77 \pm 6.11$ & $52.14 \pm 8.67$ & 0.0967 \\
\hline Creatinine $(\mathrm{mEg} / \mathrm{L})$ & $0.280 \pm 0.01$ & $0.0240 \pm 0.01$ & 0.9976 & $0.220 \pm 0.13$ & $0.038 \pm 0.01$ & 0.8663 \\
\hline
\end{tabular}

Data are presented as mean \pm S.E.M. of six animals. *compared to saline group acute toxicity. ANOVA followed by Student Newman-Keuls and Tukey's test, p<0.05. Source: Authors.

Table 3. Relative organ weights of mice treated intraperitoneally with latex proteins from Plumeria pudica (LPPp) in acute toxicity and subchronic toxicity.

\begin{tabular}{cccccc}
\hline & Treatment & Dose (mg/kg/day) & Liver (g/100g body weight) & Spleen (g/100g body weight) & Kidney (g/100g body weight) \\
\hline \multirow{2}{*}{ Acute Toxicity } & Saline & - & $4.18 \pm 0.10$ & $0.91 \pm 0.08$ & $0.55 \pm 0.049$ \\
& LPPp & 40 & $4.28 \pm 0.11$ & $0.99 \pm 0.03$ & $0.54 \pm 0.11$ \\
\hline \multirow{2}{*}{ Subchronic Toxicity } & Saline & - & $4.15 \pm 0.11$ & $0.95 \pm 0.02$ & $0.52 \pm 0.047$ \\
& LPPp & 40 & $4.16 \pm 0.09$ & $0.99 \pm 0.02$ & $0.61 \pm 0.06$
\end{tabular}

Data are presented as mean \pm S.E.M. of six animals. No statistical significance was observed between groups. ANOVA followed by Student Newman-Keuls,p $>0.05$. Source: Authors. 


\subsection{Effects of LPPp on malondialdehyde and glutathione levels}

The organs of animals submitted to the acute and subchronic toxicity tests were also investigated for antioxidant defense against the deleterious effects of reactive oxygen species. Thus, the levels of malondialdehyde (MDA) and glutathione (GSH) were investigated in the organs. The concentration of MDA in the liver, spleen and kidneys did not differ significantly between LPPp-treated animals and the saline group in the acute and subchronic toxicity tests (Figure 3). GSH content in the kidney of animals treated with LPPp reached values significantly higher than the saline control in the acute assay (Figure 4). However, no statistical differences were observed in the subchronic evaluation (Figure 4).

Figure 3. Effects of latex proteins from Plumeria pudica (LPPp) on the lipid peroxidation marker malondialdehyde (MDA) in liver, kidney and spleen of animals submitted to acute and subchronic toxicity tests. Data are presented as mean \pm SEM of six animals. No statistical difference was observed between groups. ANOVA followed by Student Newman-Keuls test, $P>0.05$.
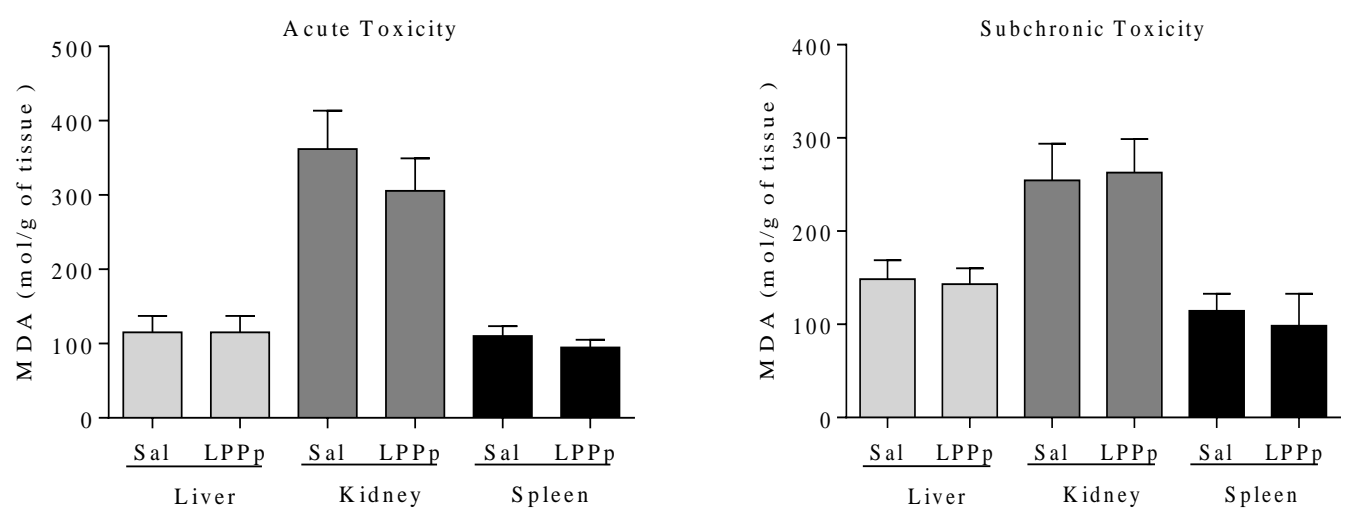

Source: Authors.

Figure 4. Effects of latex proteins from Plumeria pudica (LPPp) on reduction of the glutathione antioxidant index (GSH) in liver and kidney of animals submitted to acute and subchronic toxicity tests. Data are presented as mean \pm SEM of six animals. * indicate statistical difference compared with kidney saline group of acute toxicity. ANOVA followed by Student NewmanKeuls test, $P<0.05$.
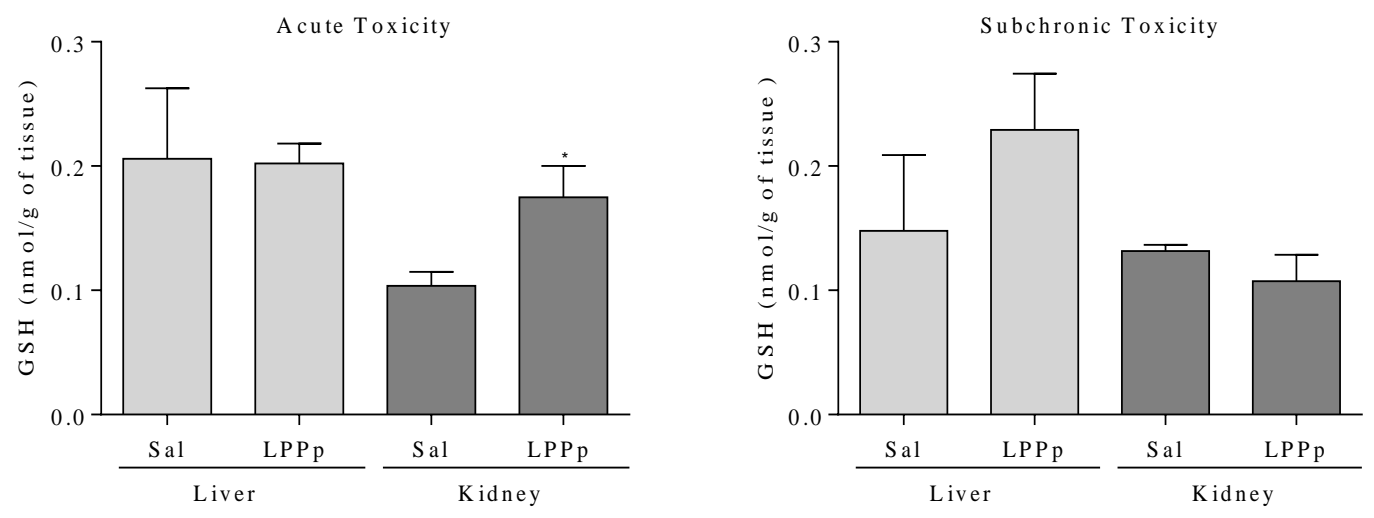

Source: Authors.

\subsection{Effects of LPPp on histopathological analysis of organs}

Histopathological analysis of liver and spleen samples from the animals submitted to LPPp treatment during 10 days and 20 days were also investigated and the results were compared to their controls (Figures. 5 and 6). The acute evaluation did 
not indicate signs of toxicity or tissue damage in the livers and spleens of the animals treated with LPPp $40 \mathrm{mg} / \mathrm{kg}$ (Figure 5.2 and 5.6). Both revealed tissue integrity, with normal morphology similar to the control group (Figures 5.1 and 5.5). However, mild glomerular capillary congestion was observed in kidney of LPPp-treated animals (Figure 5.4). These histological changes were considered as having low intensity, as presented in Table 4. No signs of toxicity or tissue damage in the livers and kidneys were observed for subchronic evaluation in the groups treated with LPPp (Figure 6.2 and 6.4). Moreover, the organs of the animals treated with LPPp were morphologically normal and similar to those of the control animals (Figures 6.1 and 6.3). Slight congestion was observed in the spleen of the experimental group (Figures 6.6).

Table 4. Histopathological evaluation of mice treated with latex proteins from Plumeria pudica (LPPp) on acute and subchronic toxicity.

\begin{tabular}{ccccccc}
\hline \multirow{2}{*}{ Parameters } & \multicolumn{2}{c}{ Acute Toxicity } & & \multicolumn{2}{c}{ Subchronic Toxicity } \\
\cline { 2 - 3 } \cline { 5 - 6 } \cline { 5 - 6 } \cline { 5 - 6 } \cline { 5 - 6 } & Saline & LPPp & & Saline & LPPp \\
\hline Liver & & & & & \\
\hline Steatosis & $0(0-1)$ & $0(0-2)$ & & $0(0-1)$ & $0(0-2)$ \\
Inflammation & $1(1-1)$ & $1(1-2)$ & & $1(1-1)$ & $1(1-2)$ \\
Necrosis score & $1(1-1)$ & $1(1-2)$ & & $1(1-1)$ & $1(1-2)$ \\
Foamy vacuolated cytoplasm & $1(1-1)$ & $1(1-2)$ & & $1(1-1)$ & $1(1-2)$ \\
Nuclear fragmentation & $1(1-1)$ & $1(1-2)$ & & $1(1-1)$ & $1(1-2)$ \\
\hline Kidneys & $0(0-0)$ & $0(0-1)$ & & $0(0-0)$ & $0(0-1)$ \\
\hline Spleen & $0(0-0)$ & $0(0-1)$ & & $0(0-0)$ & $0(0-1)$
\end{tabular}

Data are presented as mean \pm S.E.M. of six animals. There is no significant difference between the groups (Mann-Whitney test, $\mathrm{p}>0.05$ ). Source: Authors. 
Figure 5. Histopathological analysis of organs of mice treated with latex proteins from Plumeria pudica (LPPp) in the acute toxicity. Figures 5.1 and 5.2: liver; 5.3 and 5.4: kidney; 5.5 and 5.6: spleen. Figures 5.1, 5.3 and 5.5 indicate saline control group while 5.2, 5.4 and 5.6 designate mice treated with LPPp. Arrow indicates sinusoid capillary, CV the central vein, letter G the glomerulus, asterisks capsular space, circle represents normal renal tubules, WP white pulp, RP red pulp and arrows indicate trabeculae of connective tissue. Magnification of 600x for figures 5.1, 5.2, 5.3 and 5.4; 150x for figures 5.5 and 5.6. No histological alterations of organs were observed after 10 days of treatment with LPPp
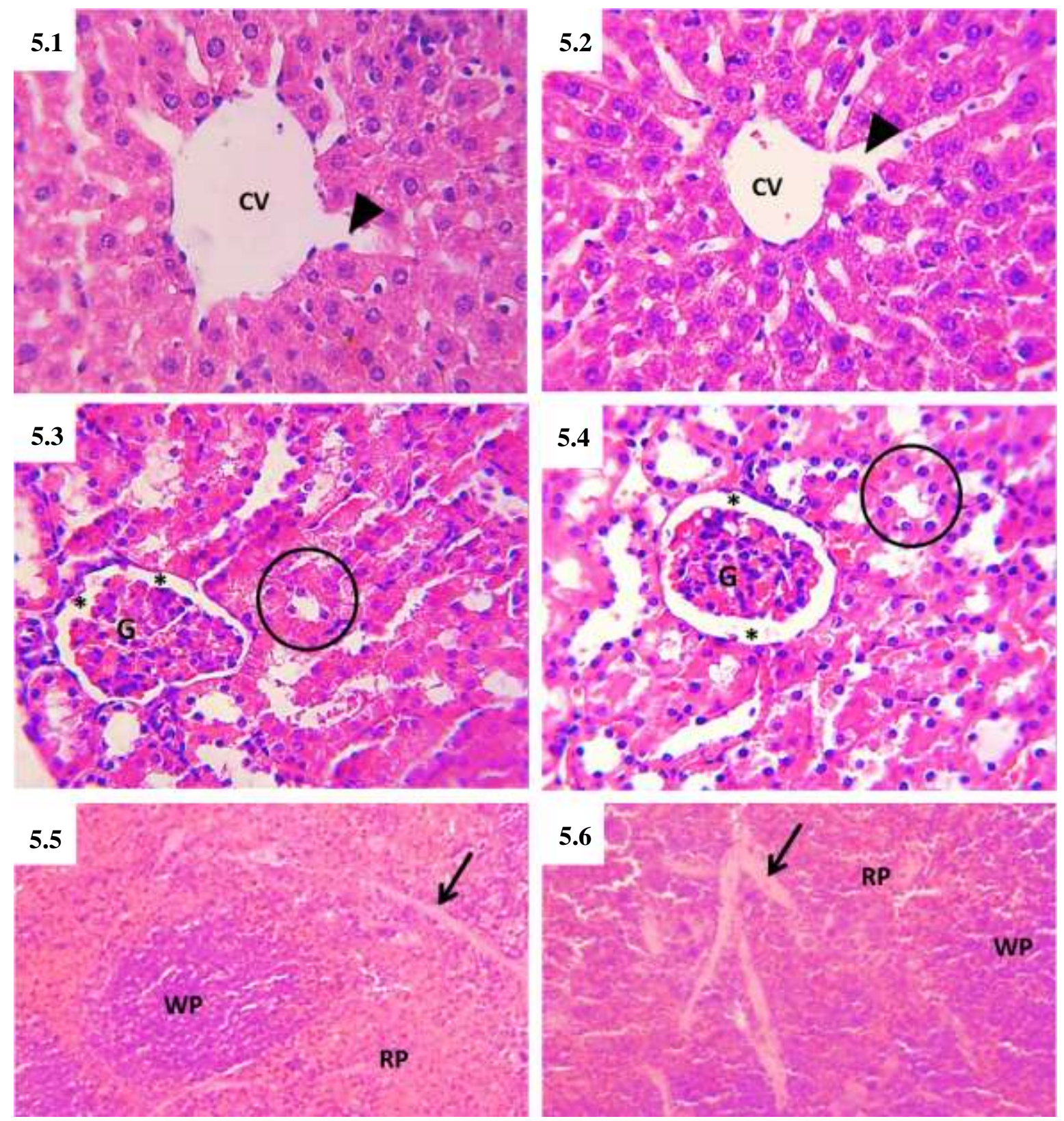

Source: Authors. 
Figure 6. Histopathological analysis of organs of mice treated with latex proteins from Plumeria pudica (LPPp) in the subchronic toxicity. Figures 6.1 and 6.2: liver; 6.3 and 6.4: kidney; 6.5 and 6.6: spleen. Figures 6.1, 6.3 and 6.5 indicate saline control group while 6.2, 6.4 and 6.6 designate mice treated with LPPp. Arrow indicates sinusoid capillary, CV the central vein, letter $\mathrm{G}$ the glomerulus, asterisks capsular space, circle represents normal renal tubules, WP white pulp, RP red pulp and arrows indicate trabeculae of connective tissue. Magnification of 600x for figures 6.1, 6.2, 6.3 and 6.4; 150x for figures 6.5 and 6.6. No histological alterations of organs were observed after 20 days of treatment with LPPp.
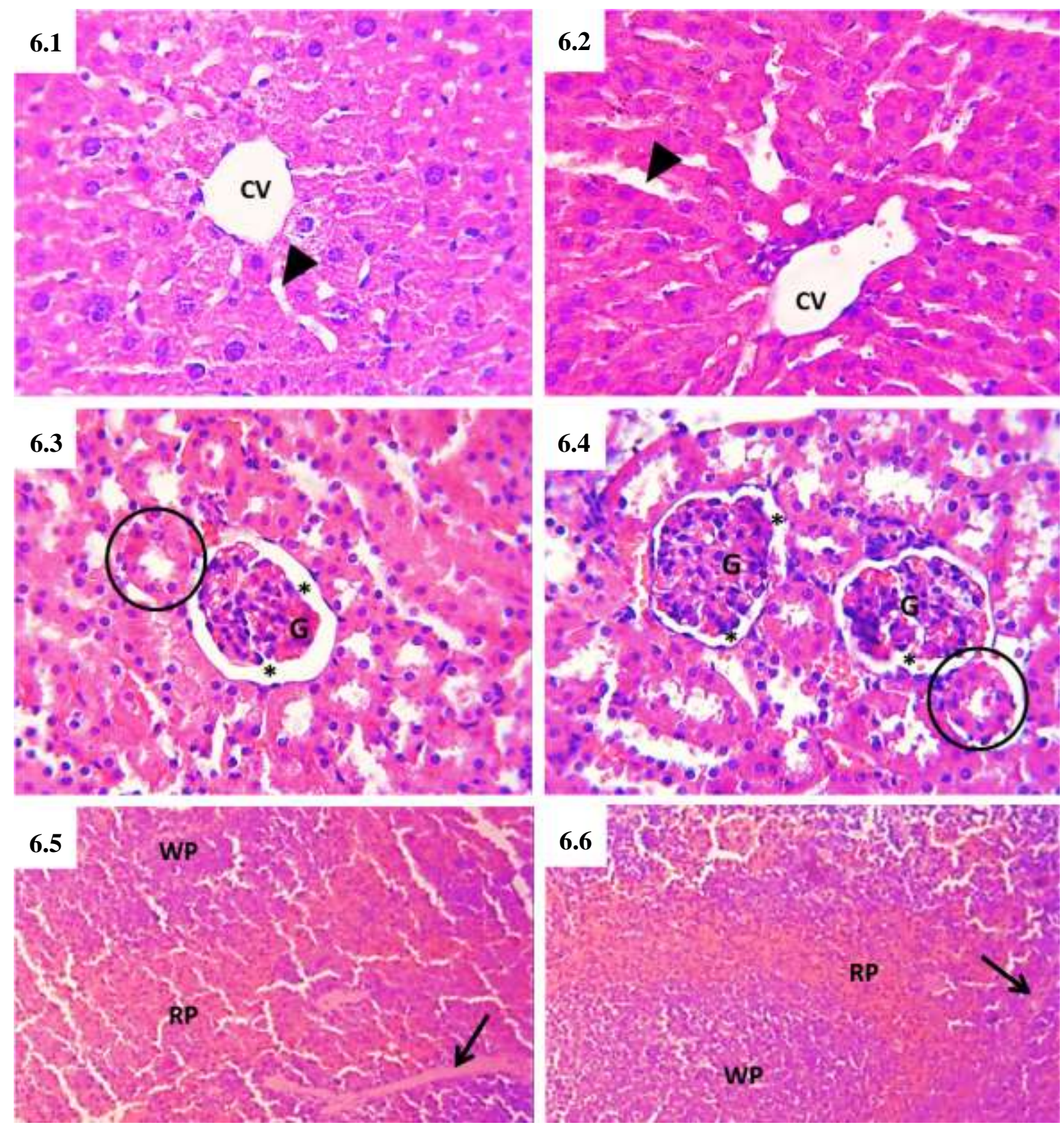

Source: Authors.

\subsection{LD $D_{50}$ of LPPp and evaluation of signs of toxicity}

In order to assess the $\mathrm{LD}_{50}$ of latex proteins from P. pudica, the animals received a single intraperitoneal dose of 300 $\mathrm{mg} / \mathrm{kg}$ or $2,000 \mathrm{mg} / \mathrm{kg}$ of LPPp. No mortality was recorded during the 14 days of evaluation for both tested doses. However, some signs of toxicity were observed during the evaluation period, mainly during first 24 hours (Table 5). In the first half hour, the animals that received $300 \mathrm{mg} / \mathrm{kg}$ of LPPp were lethargic, with decreased general activity. They walked with difficulty, dragging the hind legs. They had slower auricular, corneal and straightening reflexes, as well as reduced response to stimuli 
such as touching and tail pinching. The mice also suffered from irritability, ptosis, piloerection, hypothermia and wheezing. Most of the observed signs ended after the second hour of evaluation, except for ptosis, which was present up to the third hour, piloerection, which persisted until the seventh hour, hypothermia, which was present until the eighth hour, and irritability, which continued until the 14th day. The animals treated with $2,000 \mathrm{mg} / \mathrm{kg}$ of LPPp also presented signs of toxicity similar to those observed for animals treated with $300 \mathrm{mg} / \mathrm{kg}$. The main difference was the presence of diarrhea in the first 24 hours, lacrimation on the 13th day and the absence of corneal reflex in one animal until the last day of analysis.

Table 5. Effects of intraperitoneal administration of single doses ( 300 or 2,000 mg/kg) of latex proteins from Plumeria pudica (LPPp) in mice.

\begin{tabular}{|c|c|c|c|}
\hline Dose $\mathrm{mg} / \mathrm{kg}$ & $\mathbf{D} / \mathbf{T}^{*}$ & Time & Symptoms \\
\hline O (Control) & $0 / 3$ & $14^{\text {th }}$ day & Absent \\
\hline \multirow{5}{*}{300} & \multirow{5}{*}{$0 / 3$} & $2 \mathrm{~h}$ & $\begin{array}{c}\text { Lethargy, decreased general activity, decreased motor activity, } \\
\text { decrease of response to auricular and corneal reflexes, decreased } \\
\text { stimuli such as touch and tail grasping, righting reflex and grasping } \\
\text { strength, irritability, ptosis, piloerection, hypothermia, and accelerated } \\
\text { breathing }\end{array}$ \\
\hline & & $3 \mathrm{~h}$ & Ptosis ( 1 animal) \\
\hline & & $7 \mathrm{~h}$ & Piloerection \\
\hline & & $8 \mathrm{~h}$ & Hypothermia \\
\hline & & $14^{\text {th }}$ day & Irritability \\
\hline \multirow[t]{4}{*}{2.000} & \multirow[t]{4}{*}{$0 / 3$} & $24 \mathrm{~h}$ & $\begin{array}{l}\text { Lethargy, decreased general activity, decreased motor activity, } \\
\text { decrease of response to auricular and corneal reflexes, decreased } \\
\text { stimuli such as touch and tail grasping, righting reflex and grasping } \\
\text { strength, irritability, Straub tail reaction, ptosis, diarrhea, piloerection, } \\
\text { hypothermia and accelerated breathing }\end{array}$ \\
\hline & & 11st day & Straub tail reaction ( 1 animal) \\
\hline & & 13rd day & Lacrimation and piloerection \\
\hline & & $14^{\text {th }}$ day & Irritability, auricular reflex and corneal reflex absent in 1 animal. \\
\hline
\end{tabular}

* number of dead mice/number of treated mice. Source: Authors.

\section{Discussion}

The scientific investigation of Plumeria pudica latex has supported its folk use. For example, the folk use of this latex to ameliorate toothache by topical application is supported by the finding that proteins recovered from the latex (LPPp) inhibited important inflammatory and pain events in animal pharmacological models (Fernandes et al,2015). Our research team is investigating this protein fraction in the last years. Besides mentioned anti-inflammatory activity, we investigated its antidiarrheal properties (Santana et al;2018), its protective effect on ulcerative colitis (Oliveira et al, 2019) and its effects and periodontitis (Oliveira et al,2021) also against induced gastritis injury by ethanol (data not published). These interesting pharmacological finding and the lack of scientific studies validating LPPp safety use, motivated us to perform the current toxicological investigation. 
The toxic effects of other latexes have been previously reported. The laticifer fluid collected from Calotropis procera produced significant toxicological effects, including death, on goats after intraperitoneal, intravenous or oral administration of the whole latex (El Badwi et al,1998). It is assumed that this observed toxicity, at least in part, is caused by cis-1,4polyisoprene (rubber) and low molecular weight molecules present in samples (Alencar et al,2006). Fractionation to remove rubber and low molecular weight compounds from latex has been used to diminish its toxicity. This is confirmed since the protein alone (after removal of rubber and low molecular weight substances) from C. procera latex was found to have potent pharmacological properties and did not cause death of animals given $5,000 \mathrm{mg} / \mathrm{kg}$ orally (Alencar et al,2004; Oliveira et al,2010; Bezerra et al,2017).

Since the rubber content seems to be associated with some adverse effects of latex, we performed dialysis and centrifugation steps in an attempt to obtain a water-soluble protein fraction (LPPp) and eliminate rubber and low molecular weight elements from the latex (Fernandes et al,2015; Santana et al,2018). The removal of the rubber is not difficult, so it should not be a limitation to exploring the pharmacological uses of this plant. The rubber fraction of $P$. pudica comprises over $87 \%$ of the dry matter of the latex and $2 \%$ LPPp. The content of other compounds, such as secondary metabolites, represents $11 \%$ of the dry mass. Biochemical investigation of LPPp revealed the presence of proteins with molecular weight ranging from 14 to $45 \mathrm{kDa}$, comprising mainly cysteine proteinases, chitinases and protease inhibitors (Santana et al, Oliveira et al,2019). These class of vegetable proteins have been described as having pharmacological properties (Lee et al, 2011; Rathnavelu et al,2016; Vergnolle,2016). and may be associated to beneficial effects promoted by LPPp. On the other hand, there have been no comprehensive investigations about the possible toxic effect promoted by them.

Data obtained from this study showed that LPPp from P. pudica administered intraperitoneally at a dose of $40 \mathrm{mg} / \mathrm{kg}$ did not produce death or any significant sign of toxicity in both acute and subchronic models. In relation to body weight of LPPp-treated animals, no significant change was observed for both acute and subchronic evaluation when compared to their controls. This observation may indicate that the protein fraction of $P$. pudica did not affect the metabolism or nutrient absorption of the animals, although another study found that it affects the hormones and body weight (Cajuday\& Poscidio,2010). The weight of the organs is directly related to the metabolic activity. Thus, an important index to estimate whether an organ has been exposed to injury is to calculate the organ-to-body weight ratio (Rosidah et al,2009). Significant difference in the organ-to-body weight ratio between treated and untreated groups can be considered an indicator of organ damage (Bailey, Zidell, Perry,2004). In the present study, there were no significant changes in the relative weights of organs between the control and mice treated with LPPp for both acute and subchronic toxicity, suggesting no glossy toxic effect from the LPPp.

Other signs of toxicity measured by analysis of hematological and biochemical parameters are relevant for risk evaluation, since changes in the hematological system in animals are also found in humans most of the time (Olson \& Betton, 2000). In this respect, the total and differential blood cell count of the animals that received LPPp showed no significant difference with control groups. Among the biochemical parameters, those related to liver (AST and ALT) and kidney (creatinine and urea) function was analyzed. The concentration of AST in the group treated with LPPp for 10 days (acute toxicity) showed a significant increase compared to respective control. However, the level of AST in the group treated during 20 days (subchronic toxicity) was smaller and statistically similar to the control. The levels of ALT in the groups receiving LPPp in acute and subchronic toxicity tests did not differ from the respective control groups. AST and ALT are enzymes found in high concentrations in muscle, liver and brain, and the elevation of their activity in the blood may be related to necrosis in these tissues (Motta, 2003). However, absence of microscopic lesions in the liver allows inferring that the increase of AST is not due to tissue injuries, and demonstrates the reversibility of possible toxic effects, indicating the ability of the body to react when receiving LPPp (Eaton \& Klaassen, 1996). 
Considering kidney function, increased blood levels of creatinine and urea are good indicators of negative impact on kidney functions, so measurement of their concentrations are used for the assessment of renal sufficiency (Rhiouani et $\mathrm{al}$,2008). The absence of effects on these parameters for both acute and subchronic evaluation suggests that LPPp did not cause renal failure, although slight congestion was observed in the kidneys of animals receiving LPPp in the acute evaluation. Histological observation of mild congestion can be a normal finding after necropsy, because when the animal dies the circulating blood remains in the organ. Moreover, the event can also be classified as a discrete, transitory and reversible toxic effect.

The level of the enzyme myeloperoxidase (MPO) was measured in liver, kidney and spleen samples from animals treated with LPPp in order to evaluate the development of inflammatory processes. This enzyme is present in the granules of these cells in its inactive form, so increase of its activity indirectly indicates neutrophil infiltration (Dallegri \& Ottonello, 1997) our results showed that LPPp did not promote a tissue inflammatory process since LPPp treatment did not alter the MPO activity of the evaluated organs in both acute and subchronic treatments.

The increment of MPO activity increases the levels of free radicals as part of the innate immune response of the host (Arnhold \& Flemming, 2010). These free radicals oxidize cell systems and membranes, causing cell damage or death (Welborn et al, 1991). Although LPPp did not increase tissue MPO levels, the possible cellular oxidative stress associated with LPPp treatment was assessed in the kidney, liver and spleen by measuring levels of GSH and MDA. Both biomarkers are widely used for evaluation of tissue oxidative stress (Chiurchiù \& Maccarrone, 2016). In a toxicological evaluation, accumulation of oxygen-reactive species or loss of antioxidant capacity can result in an increased chance of oxidative damage or cell death (Perandin et al, 2015)

In the present study, despite the increase in liver GSH values in animals treated with LPPp in subchronic investigation, no significant differences were found among groups submitted to acute and subchronic evaluation. The levels of GSH in the kidneys significantly increased during the acute evaluation and decreased in subchronic toxicity group. Additionally, tissue MDA levels were similar among groups for both acute and subchronic evaluation of LPPp treatment. In fact, we expected LPPp treatment not to interfere in overall values of MPO, GSH and MDA, since LPPp inhibited their alterations when inflammatory process was induced (Fernandes et al, 2015; Santana et al,2018, Oliveira et al,2019; Oliveira et $\mathrm{al}, 2021$ ). Additionally, no signs of oxidative damage or inflammatory process were observed in histopathological evaluation of kidneys, livers and spleens of animals treated with LPPp for 10 or 20 days, corroborating the results of biochemical evaluation.

The $\mathrm{LD}_{50}$ for the intraperitoneal administration of proteins from $P$. pudica was estimated to be higher than 2,000 $\mathrm{mg} / \mathrm{kg}$. In this case, according to the OECD directive, the administration of LPPp can be considered practically nontoxic, or at worst slightly toxic. Although deaths did not occur in the 14 days after administration of LPPp (single dose of $300 \mathrm{mg} / \mathrm{kg}$ or $2,000 \mathrm{mg} / \mathrm{kg}$ ), behavioral alterations were seen in the first hours after administration. However, the majority of these alterations did not persist for more than 24 hours and they were not observed on animals receiving $40 \mathrm{mg} / \mathrm{kg}$ during acute and subchronic toxicological evaluations.

\section{Conclusion}

Our data indicate the absence or low toxicity of intraperitoneal administration of $40 \mathrm{mg} / \mathrm{kg}$ of LPPp, the same dose previously demonstrated to exhibit anti-inflammatory and antidiarrheal effects, and protective effect during ulcerative colitis. The complex molecular composition of LPPp makes it difficult to determine the exact molecule involved in the pharmacological activity or its possible toxic properties. The process of fractionation of LPPp to identify its constituents is now in progress and will contribute significantly to characterize the proteins from P. pudica latex as well as to indicate the direction to be followed for purification of the active principles. The results presented here are an important advance in the 
understanding of LPPp's toxicological properties. Now LPPp is target to fractionation using chromatography steps in order to purify proteins to be identified and thus investigate their pharmacological and toxicological properties.

\section{Acknowledgments}

We gratefully acknowledge the financial support from the National Council for Technological and Scientific Development (CNPq, Brazil, no. 406733/2013-9 and no. 446497/2014-2).

\section{Conflict of Interest}

The authors declare no conflicts of interest.

\section{Ethical Issues}

The project was approved by the guidelines of the institutional animal ethics Committee from Federal University of Piauí (Protocol No. 037/15).

\section{References}

Agra, M. F., França, P. F. \& Barbosa-Filho, J. M. (2007). Synopsis of the plants known as medicinal and poisonous in Northeast of Brazil. Revista Brasileira de Farmacognosia, 17(1), 114-140. http://dx.doi.org/10.1590/S0102-695X2007000100021.

Agrawal, A. A. \& Konno, K. (2009). Latex: a model for understanding mechanisms, ecology and evolution plant defense against herbivory. The Annual Review of Ecology, Evolution and Systematics, 40, 311-331. https://doi.org/10.1146/annurev.ecolsys.110308.120307.

Alencar, N. M. N., Figueiredo, I. S. T., Vale, M. R.; Bitencurt, F. S., Oliveira, J. S., Ribeiro, R. A. \& Ramos, M. V. (2004). Anti-inflammatory effect of the latex from Calotropis procera in three different experimental models: peritonitis, paw edema and hemorrhagic cystitis. Planta Medica, 70 (12), 1144-1149. https://doi.org /10.1055/s-2004-835842.

Alencar, N. M. N., Oliveira, J. S., Mesquita, R. O., Lima, M. W., Vale, M. R., Etchells, J. P., Freitas, C. D. T. \& Ramos, M. V. (2006). Pro- and antiinflammatory activities of the latex from Calotropis procera (Ait.) R.Br. are trigged by compounds fractionated by dialysis, Inflammation Research., 55, 559564. https://doi.org / 0.1007/s00011-006-6025-y.

Alencar, N. M. N., Pinheiro, R. S. P.; Figueiredo, I. S. T., Luz, P. B, Freitas, L. B. N., Souza T. F. G., Carmo, L. D., Marques, L. M. \& Ramos, M. V. (2015). The Preventive Effect on Ethanol-Induced Gastric Lesions of the Medicinal Plant Plumeria rubra: Involvement of the Latex Proteins in the NO/cGMP/KATP Signaling Pathway. Evidence-Based Complementary and Alternative Medicine, 2015:706782. https://doi.org./10.1155/2015/706782.

Arnhold, J. \& Flemming, J. Humam myeloperoxidase in innate and acquired immunity. (2010). Archives of Biochemistry and Biophysics, 500 (1), 92-106. https://doi.org./10.1016/j.abb.2010.04.008.

Baghel, A. S., Mishra, C. K., Rani, A., Sasmal, D. \& Nema, R. K. (2010). Antibacterial activity of Plumeria rubra Linn. plant extract. Journal of Chemical and Pharmaceutical Research, 6, 435-440. https://doi.org./10.5897/JMPR12.223.

Bailey, S. A., Zidell, R. H \& Perry, R. W. (2004). Relationships Between Organ Weight and Body/ Brain Weight in the Rat: What Is this Best Analytical Endpoint? Toxicologic Pathology, 32 (4), 448-466. https://doi.org./10.1080/01926230490465874.

Bezerra, C. F., Mota, E. F., Silva, A. C. M., Tomé, A. R., Silva, M. Z. R., Brito, D., Porfírio, C. T. M. N., Oliveira, A. C., Lima-Filho, J. V. \& Ramos MV. (2017). Latex proteins from Calotropis procera: Toxicity and immunological tolerance revisited. Chemico-Biological Interactions, 274 (25), 138-149. https://doi.org/10.1016/j.cbi.2017.07.007.

Bradley, P. P., Priebat, D. A., Christensen, R. D \& Rothstein G. (1982). Measurement of cutaneous inflammation: estimation of neutrophil content with anenzyme marker. Journal of Investigative Dermatology, 78 (3), 206-209. https://doi.org./ 10.1111/1523-1747.ep12506462.

Brito, A. S. (1994). Manual de Ensaios Toxicológicos in vivo. São Paulo, Brasil: Ed.; UNICAMP.

Cajuday, A. L \& Poscidio, L. G. (2010). Effects of Moringa oleifera Lam: (Moringaceae) on the reproduction of male mice (Mus musculus). The Journal of Medicinal Plants Research, 4(12), 1115-1121. https://doi.org/10.5897/JMPR09.200.

Chiurchiù, V. \& Maccarrone, M. (2016). Bioactive lipids as modulators of immunity, inflammation and emotions. Current Opinion in Pharmacology, 29,54 62. https://doi.org./ 10.1016/j.coph.2016.06.005.

Choudhary, M., Kumar, V. \& Singh, S. (2014). Phytochemical and Pharmacological activity of Genus Plumeria: An updated review. International Journal of Biomedical and Advance Research, 5, 266-271. https://doi.org./10.7439/ijbar.v5i6.761.

Christapher, P. V., Mohd, S. P., Asmawi, Z., Murugaiyah, V. (2017). Acute and subchronic toxicity studies of methanol extract of Polygonum minus leaves in Sprague Dawley rats., Regulatory Toxicology and Pharmacology, 86, 33-41. https://doi.org./ doi: 10.1016/j.yrtph.2017.02.005. 
Dallegri, F. \& Ottonello, L. (1997). Tissue injury in neutrophilic inflammation. Inflammation Research, 46, 382-91. https://doi.org./ 10.1007/s000110050208.

Devprakash, T. R., Gurav, S., Kumar, G. P. S. \& Mani, T. T. (2012). A review of phytochemical constituents \& pharmacological activity of Plumeria species. International Journal of Current Pharmaceutical Research, 4 (1), 1-6.

Dwivedi, S., Shriwas, S. \& Dubey, R. (2017). Traditional phytotherapy among tribal and local villages of Madhya Pradesh, India used in the treatment of Gynecological Disorders. International Journal of Pharmaceutical and Life Sciences, 8 (11), 18.

Eaton, D. L. \& Klaassen, C. D. (1996). Principles of toxicology. In Casarett \& Doulls' toxicology: The basic science of poisons, 5th ed. New York: The United States of America, McGraw-Hill, 463-86.

El Badwi, S. M. A., Adam, S. E., Shigidi, M. T \& Hapke, H. J. (1998). Studies on laticiferous plants: toxic effects in goats of Calotropis procera latex given by different routes of administration. Deutsche Tierarztliche Wochenschrift, 105(11), 425-427.

Fernandes, H. F., Machado, D. L., Dias, J. M., Brito, T. V., Batista, J. A., Silva, R. O., Pereira, A. C. T. C., Ferreira, G. P., Ramos, M. V., Medeiros, J. V. R., Aragão, K. S., Ribeiro, R. A., Barbosa, A. L. R. \& Oliveira, J. S. (2015). Laticifer proteins from Plumeria pudica inhibit the inflammatory and nociceptive responses by decreasing the action of inflammatory mediators and pro-inflammatory cytokines., Revista Brasileira de Farmacognosia, 25 (3), 269-277. https://doi.org/10.1016/j.bjp.2015.05.003.

Gupta, M., Mazumder, U. K., Gomathi. P. \& Selvan, V. T. (2006). Anti-inflammatory evaluation of leaves of Plumeria acuminate. BMC Complementary Medicine and Therapies, 6 (36), 1472-6882. . https://doi.org/ 10.1186/1472-6882-6-36.

Lee, C. G., Silva, C. A., Dela, C. S., Ahangari, F., Ma, B., Kang, M. J., He, C. H., Takyar, S. \& Elias, J. A. (2011). Role of chitin and chitinase/chitinase-like proteins in inflammation, tissue remodeling, and injury, Annual Review of Physiology 73, 479-501. https://doi.org/10.1146/annurev-physiol-012110-142250.

Memariani, Z., Farzaei, M. H., Ali, A. \& Momtaz S. (2020). Nutritional and bioactive characterization of unexplored food rich in phytonutrients. In Woodhead Publishing Series in Food Science, Technology and Nutrition, Phytonutrients in Food, Woodhead Publishing, 157-175.

Mengue, S. S., Ments, L. A. \& Schenkel, E. P. (2001). Uso de plantas medicinais durante a gravidez. In: Sanseverino, MTV, Spritzel DT, Schüler-Faccini L. (Org). Manual de Teratogênese. Porto Alegre, Brasil: Ed. da Universidade/UFRGS, 423-450.

Motta, V. T. (2003). Bioquímica Clínica para o Laboratório: princípios e interpretações. (4a ed.), Robe Editorial.

OECD (Organization for Economic Cooperation and Development). (2008). Test No. 407: Repeated Dose 28-day Oral Toxicity Study in Rodents, Guidelines for the Testing of Chemicals, Section 4, OECD Publishing, Paris, 2008.

OECD (Organization for Economic Cooperation and Development). (2001). Test No. 423. Acute oral toxicity: acute toxic class method. Guideline for the Testing of Chemicals, Section 4, OECD Publishing, Paris, 2001.

Oliveira, J. S., Costa-Lotufo, L. V., Bezerra, D. P., Alencar, N. M. N., Marinho-Filho, J. D. B., Figueiredo, I. S. T., Moraes, M. O., Pessoa, C, Alves. A. P. N. N. \& Ramos, M. V. (2010). In vivo growth inhibition of sarcoma 180 by latex proteins from Calotropis procera. Naunyn-Schmiedeberg's Archives of Pharmacology, 382 (2),139-149. https://doi.org/ 10.1007/s00210-010-0525-6.

Oliveira, N. T. \& Almeida, S. S. M. (2016). Análise fitoquímica, citotóxica e antimicrobiana do extrato bruto etanólico das folhas da espécie Ambelania acida Aublet (Apocynaceae). Biota Amazônia, 6, 20-25.

Oliveira, N. V. M., Souza, B. S., Moita, L. A., Oliveira, L. E. S, Brito, F. C., Magalhães, D. V., Batista, J. A., Sousa, S. G., Brito, T. V., Sousa, F. B. M., Alves, E. H. P., Vasconcelos, D. F. P., Freitas, C. D. T., Ramos, M. V., Barbosa, A. L. R \& Oliveira JS (2019). Proteins from Plumeria pudica latex exhibit protective effect in acetic acid induced colitis in mice by inhibition of pro- inflammatory mechanisms and oxidative stress. Life Sciences, 231(15), 1-8. https://doi.org/ 10.1016/j.lfs.2019.06.010.

Oliveira, L. E. S, Moita, L. A., Souza, B. S., Oliveira, N. M. V., Sales, A. C. S., Barbosa, M. S., Silva, F. D. S., Farias, A. L. C., Lopes, V. L. R., França, L. F. C., Alves, E. H. P., Freitas, C. D. T., Ramos, M. V., Vasconcelos, D. F. P. \& Oliveira JS. (2021). Latex proteins from Plumeria pudica reduce ligature-induced periodontitis in rats. Oral Diseases, 00, 1-10. https://doi.org/10.1111/odi.13803.

Olson, H., Betton,G., Robinson. D., Monro, A., Kolaja, G., Lilly, P., Sanders, J., Sipes, G., Bracken, W., Dorato, M., Van Deun, K., Smith, P., Berger, B. \& Heller, A. (2000). Concordance of the toxicity of pharmaceuticals in humans and in animals. Regulatory Toxicology and Pharmacology, 32 (1), 56-67. https://doi.org/ 10.1006/rtph.2000.1399.

Perandin, D., Maioli, M. A., Santos, P. R. S., Pereira, F. T. V., \& Mingatto, F. E. (2015). Proteção do dano oxidativo hepático induzido por ferro pelo extrato aquoso da planta Plectranthus barbatus. Revista brasileira de plantas medicinais, 17(1),9-17. https://doi.org/10.1590/1983-084X/12_019.

Ramos, M. V., Aguiar, V. C., Melo, V. M. M., Mesquita, R. O., Silvestre, P. P., Oliveira, J. S., Oliveira, R. S. B., Macedo, N. M. R. \& Alencar, N. M. N. (2007). Immunological and allergenic responses induced by latex fractions of Calotropis procera (Ait.) R. Br.Journal of Ethnopharmacology, 111 (1), 115122. https://doi.org/ 10.1016/j.jep.2006.10.034.

Rathnavelu, V., Alitheen, N. B., Sohila, S., Kanagesan, S. \& Ramesh, R. (2016). Potential role of bromelain in clinical and therapeutic applications. Biomed Rep, 5 (3), 283-288. https://doi.org/10.3892/br.2016.720.

Rhiouani H, El-Hilaly J, Israili HZ, Lyoussi B. (2008). Acute and sub-chronic toxicity of an aqueous extract of the leaves of Herniaria glabra in rodents. Journal of Ethnopharmacology, 118 (13), 378-386. https://doi.org/10.1016/j.jep.2008.05.009.

Rosidah, M. F. Y., Sadikun, A., Ahmad. M., Gabriel, A. A. \& Mohd, Z. A. (2009). Toxicology evaluation of standardized methanol extract of Gynura procumbens. Journal of Ethnopharmacology, 123, 244-249. https://doi.org/10.1016/j.jep.2009.03.011.

Sampieri, R. H., Collado, C. F. \& Lucio, M. D. P. B. (2013). Metodologia de Pesquisa (5a ed.). McGraw-Hill. 
Research, Society and Development, v. 10, n. 6, e58610616174, 2021

(CC BY 4.0) | ISSN 2525-3409 | DOI: http://dx.doi.org/10.33448/rsd-v10i6.16174

Santana, L. A. B., Aragão, D. P., Araújo, T. S. L., Sousa, N. A., Souza, L. K. M., Oliveira, L. E. S., Pereira, A. C. T. C., Ferreira, G. P., Oliveira, N. V. M., Souza, B. S., Sousa, F. B. M., Ramos. M. V., Freitas, C. D. T., Medeiros, J. V. R \& Oliveira, J. S. (2018). Antidiarrheal effects of water-soluble proteins from Plumeria pudica latex in mice. Biomedicine \& Pharmacotherapy, 97, 1147-1154. https://doi.org/10.1016/j.biopha.2017.11.019.

Sedlak, J., Lindsay, R. H. (1968). Estimation of total, protein-bound, and nonprotein sulfhydryl groups in tissue with Ellman's reagent. Analytical Biochemistry, 25, 192-205. https://doi.org/10.1016/0003-2697(68)90092-4.

Shinde, P. R., Patil, P. S., \& Bairagi, V. A. (2014). Phytopharmacological Review of Plumeria species. Scholars Academic Journal of Pharmacy, 3,217-227.

Silveira, P. F., Bandeira, M. A. M. \& Arrais, P. S. D. (2008). Farmacovigilância e reações adversas às plantas medicinais e fitoterápicos: uma realidade. Revista Brasileira de Farmacognosia, 18(4),618-626. https://doi.org/10.1590/S0102-695X2008000400021.

Subramanian, K. Sankaramourthy D., \& Gunasekaran M. (2018). Chapter 18. Toxicity Studies Related to Medicinal Plants. In: Natural Products and Drug Discovery, USA, Elsevier, 491-505.

Uchiyama, M., \& Mihara, M. (1978). Determination of malonedialdehyde precursor in tissues by thiobarbituric acid test. Analytical Biochemistry, 86 (1), 271 278. https://doi.org/10.1016/0003-2697(78)90342-1.

Veiga-Júnior, V. F., Pinto, A. C., \& Maciel, M. A. M. (2005). Plantas medicinais: cura segura? Quimíca Nova, 28(3),519-528. http://dx.doi.org/10.1590/S0100-40422005000300026.

Vergnolle, N. (2016). Protease inhibition as new therapeutic strategy for GI diseases. Gut, 65 (7), 1215-1224. https://doi.org/10.1136/gutjnl-2015-309147.

Welborn, C. R., Goldman, G., Peterson, J. S., Valeri, C. R., Shepro, D., \& Hechtman, H. B. (1991). Pathophysiology of ischemia-reperfusion on injury: central role of the neutrophil. British Journal of Surgery, 78, 651-5. https://doi.org/10.1002/bjs.1800780607.

World Health Organization (WHO). (2013). WHO traditional medicine strategy 2014-2023. WHO. 